\title{
About the 1994-95 Seminar on Lacan
}

\author{
ALAIN BADIOU
}

S ince the late 1950s, Lacan has been as indispensable a companion along my intellectual journey as he has been a difficult one. He's been indispensable because it was through him that I found the means to effect a synthesis between the idea of the free Subject, which I'd enthusiastically embraced in my Sartrean youth, and that of the importance of formal structures, inspired by my long-standing admiration for Plato, my love of mathematics, and the Structuralist current that had begun to dominate the intellectual scene. And he's been difficult, because, even though Lacan constantly worked "with" philosophers, from Plato and Aristotle to Heidegger by way of Descartes, Kant, Hegel, and Kierkegaard, he not only refused to be identified as a philosopher-increasingly so as his system of thought took shape-but he also made a point of playing up a marked difference between the discourse of psychoanalysis and the discourse of philosophy. He ultimately summed up his position as being that of an "anti-philosopher," an eighteenth-century term that he revived. Since a rigorous practice, the analytic clinic, was the real on which his thinking was based, Lacan could only see in the philosophical discourse a pretension of thought to dispense with the real. 
Before I began the seminar you're about to read, I had written a great many texts on Lacan, right from the time I was involved in the Cahiers pour l'analyse, during the years 1966-1968. The most important of these can be found under the general heading "Philosophy and Psychoanalysis" in my book Conditions (Seuil, 1992; English edition, Continuum, 2008). It is clear to me, on rereading them, how they counterbalance an unqualified admiration for almost everything to do with the pure doctrine of the Subject against a stubborn resistance to almost everything to do with the Subject's linkage to both the real of being and the arrangements of the symbolic order, with the crux of the issue ultimately concerning what might be called "the being of truths."

I should add, and this is of no little importance, that the last chapter of Being and Event-Meditation 37-is entitled "Descartes/ Lacan" and that I therefore conclude my ontological treatise with my paradoxical relationship to two of the foremost contributors to the ongoing renewal, in which I presume to participate, of the category of Subject.

There is no better evidence that this vexed, or vexatious, fidelity has lasted up until today than Lacan's strategic position in my second "big" systematic treatise, Logics of Worlds (Seuil, 20o6; English edition, Continuum, 2009). Book VII, the last book in it, tackles the very difficult problem of the "body" of truths, hence of their material existence in determinate worlds. The author of reference, to whom the whole second section of Book VII is devoted, is none other than Lacan. I agree almost entirely with his theory of the subjective functions of the body, except that I have to reject his position that the Absolute is, in his words, "an initial error in philosophy" (Television, 108), which, as he sees it, seeks to "suture the hole [béance] in the subject." He's clearly a difficult companion, Lacan.

The 1994-95 seminar is part of a tetralogy devoted, as it happens, to the most well-known anti-philosophers. Although the tetralogy 
concludes with a key apostle of anti-philosophy, namely, Saint Paul, it deals first with modern anti-philosophers-Nietzsche (1992-93), Wittgenstein (1993-94), and Lacan-as opposed to the trio of classical anti-philosophers-Pascal, Rousseau, and Kierkegaard-to whom I may one day devote seminars. They amply deserve as much and are moreover already very frequently mentioned in my books.

As regards Lacan, the aim of the seminar was to focus more closely on the foundations of his anti-philosophy rather than to provide a general overview of his work. So the texts most often used were from Lacan's last "style," which, in privileging the real over the symbolic and topology over algebra, attempts to structure the analytic experience less on the basis of a logic-such as the logic of the signifierthan on the basis of the dialectic between knots and cuts, mazes and gaps, tangled paths and random clearings. Along with this, as a major shift, there is a strategic function of the mysterious jouissance, whereas in the first part of his project Lacan had instead attempted to isolate desire-to distinguish it from demand-by using a strictly symbolic determination of its object.

As you'll see, disagreement is constantly mixed with amazement at the Master's creative ideas. You make your way as best you can, in the underbrush at times. But you come across so many crucial formulations! Of all these verbal treasures, the one that stands out for me is that the goal of analytic treatment is to "raise impotence to impossibility." The ultimate paradox is that this may well be the definition I've been seeking for ages (and which Lacan had already come up with long ago for a completely different purpose): the definition of ... philosophy.

Alain Badiou, February 2013 
